TAZKIR: Jurnal Penelitian Ilmu-ilmu Sosial dan Keislaman

Web: jurnal.iain-padangsidimpuan.ac.id/index.php/TZ/

Vol. 05 No. 1 Juni 2019

DOI: http://dx.doi.org/10.24952/tazkir.v5i1.1509

\title{
TANGGUNG JAWAB PENDIDIKAN MENURUT ALQURAN
}

\section{DEDI SAHPUTRA NAPITUPULU}

Dosen STIT Al-Ittihadiyah Labuhanbatu Utara

Email: dedisahputranapitupulu@yahoo.com

DOI: http://dx.doi.org/10.24952/tazkir.v5i1.1509

\begin{abstract}
Education is the most important factor in shaping human resources superior. In order to realize quality education so many factors that are responsible for and actively involved in advancing education. The following description is trying to explain the responsibilities of education based on the approach to librarianship and through analysis of the interpretation of the Qur'anic verses relating to responsibility for education. Specifically verses that will be examined is the surah Luqman/31:12-19 and Surah at-Tahrim/66:6. The results of the analysis of the research indicates that real education responsibilities given to four groups, namely: 1) parents as the first educators, 2) Educators/teachers that provide formal science at educational institutions, 3) Learners as people who need guidance, and 4 facilitate the sustainability of the Government) of education.
\end{abstract}

Keywords: Responsibility, Education, Quran

\begin{abstract}
Abstrak
Pendidikan merupakan faktor terpenting dalam membentuk sumber daya manusia yang unggul. Dalam rangka mewujudkan pendidikan yang berkualitas maka banyak faktor yang bertanggung jawab serta terlibat aktif dalam memajukan pendidikan. Uraian berikut ini berusaha menjelaskan tanggung jawab pendidikan berdasarkan pendekatan kepustakaan dan melalui analisis tafsir ayat-ayat Alquran yang berhubungan dengan tanggung jawab pendidikan. Secara khusus ayat yang akan dikaji adalah surah Luqman/31: 12-19 dan surah atTahrim/66: 6. Hasil analisis penelitian ini menunjukkan bahwa tanggung jawab pendidikan sesungguhnya diberikan kepada empat kelompok yaitu: 1) Orang tua sebagai pendidik pertama, 2) Pendidik/guru yang memberikan ilmu pengetahuan secara formal pada lembaga pendidikan, 3) Peserta didik sebagai orang yang memerlukan bimbingan, dan 4) Pemerintah yang memfasilitasi keberlangsungan pendidikan.
\end{abstract}

Kata Kunci: Tanggung jawab, Pendidikan, Alquran 
26 | TAZKIR: Jurnal Penelitian Ilmu-ilmu Sosial dan Keislaman

Vol. 05 No. 1 Juni 2019

\section{PENDAHULUAN}

Keberhasilan pendidikan tidak dapat dipisahkan dari faktor-faktor pendidikan. Diantara faktor tersebut adalah apa yang pernah disebutkan oleh bapak pendidikan Indonesia Ki. Hadjar Dewantara yakni: keluarga, sekolah dan masyarakat, ini lah yang kemudian dikenal dengan tri pusat pendidikan. Keluarga merupakan faktor terpenting dalam menentukan keberhasilan pendidikan, karena keluarga menjadi madrasah pertama bagi seorang anak. Oleh karena itu membangun keluarga yang harmonis sesungguhnya merupakan investasi bagi masa depan pendidikan anak.

Selain dari faktor pendidikan, tanggung jawab pendidikan juga ikut menjadi indikator dari keberhasilan pendidikan. Tanggung jawab dalam dunia pendidikan paling tidak diberikan kepada orang tua, guru, peserta didik, dan pemerintah. Islam mengajarkan agar tanggung jawab yang diberikan harus dilaksanakan sebaik-baiknya. Karena setiap orang nantinya akan dimintai pertanggungjawaban terhadap apa yang telah dikerjakan semasa hidup di dunia. Oleh karena itu memahami apa yang sebenarnya menjadi tugas orang tua sebagai pendidik pertama, tugas guru sebagai perpanjangan tangan orang tua, tugas peserta didik yang memiliki tanggung jawab internal, begitu juga dengan pemerintah yang wajib menyediakan fasilitas pendidikan menjadi sangat penting. Karenanya masing-masing yang bertanggungjawab terhadap pendidikan haruslah mengenenal tugas pokok dan fungsi mereka.

Uraian berikut ini berusaha untuk menjawab persoalan-persoalan di atas, uraian paragraf demi paragraf berikut ini akan menganalisis indikator tanggung jawab pendidikan, ayat-ayat yang berhubungan dengan tanggung jawab pendidikan serta penjelasannya dengan menggunakan pendekatan tafsir dan literatur primer. 


\section{KAJIAN PUSTAKA}

\section{Tanggung jawab Pendidikan}

Sebagai mana yang kita maklum bersama bahwa, tanggung jawab merupakan sikap menerima akibat terhadap segala sesuatu yang terjadi. Dalam konteks ini, tanggung jawab yang dimaksud adalah tanggung jawab dalam bidang pendidikan, yaitu siapa yang lebih berperan dalam hal peningkatan mutu pendidikan. Tanggung jawab adalah keadaan wajib menanggung segala sesuatunya. ${ }^{1}$ Joko Tri Prasetya dalam bukunya yang berjudul Ilmu Budaya Dasar memberikan definisi tanggung jawab sebagai kesadaran manusia dalam bertingkah laku baik yang disengaja maupun tidak, atau tanggung jawab juga memiliki makna perwujudan kesadaran atas kewajiban yang dibebankan kepada seseorang. ${ }^{2}$

Di dalam Alquran tanggung jawab ini merupakan hal yang sangat fundamental yang menjadi perhatian penting bagi setiap Muslim, hal ini dapat dilihat dalam surah al-Isra' $/ 19: 36$

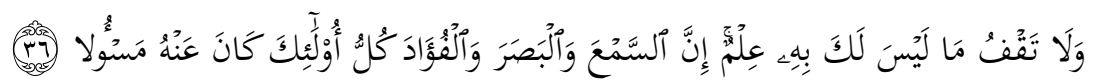

Artinya: "Dan janganlah kamu mengikuti apa yang kamu tidak mempunyai pengetahuan tentangnya. Sesungguhnya pendengaran, penglihatan dan hati, semuanya itu akan diminta pertanggungan jawabnya".

Menurut ayat di atas bahwa segala apa yang dilihat, didengar dan tersirat dalam diri manusia akan diminta pertanggungjawabannya. Singkatnya, tanggung jawab merupakan kewajiban melaksanakan tugas tertentu karena wewenag telah diterima terlebih dahulu. Kewajiban ada karena wewenang telah diterima. Oleh karena itu tanggung jawab merupakan hal yang wajib dikerjakan oleh orang yang telah diberi wewenag. Dalam kaitannya dengan pendidikan, siapa sebenarnya yang telah diberikan wewenag penuh dalam melaksanakan tugas pendidikan?. Masalah ini lah yang coba akan diuraikan kemudian.

\footnotetext{
${ }^{1}$ Departemen Pendidikan Nasional, Kamus Besar Bahasa Indonesia: Edisi Ketiga (Jakarta: Balai Pustaka, 2007), hlm. 118.

2Joko Tri Prasetya, Ilmu Budaya Dasar (Jakarta: Rineka Cipta, 1998), hlm. 154.
} 
Dalam skala yang terkecil, orang tua merupakan pemikul tanggung jawab terbesar bagi anak-anaknya. ${ }^{3} \mathrm{Hal}$ ini sesuai dengan yang disebutkan oleh Hery Noer Aly bahwa orang tua baik ayah maupun ibu mempunyai tanggung jawab yang sama terhadap pendidikan anaknya ${ }^{4}$ Sebab secara alamiah anak pada masa awal kehidupannya berada di tengah-tengah ibu dan bapaknya dari sinilah kemudian anak memperoleh pendidikan, baik itu sikap hidup, pandangan hidup sampai kepada keterampilan hidup.

Menurut Zakiah Daradjat, bahwa dalam masalah pendidikan orang tua merupakan pendidik utama dan pertama bagi anak-anaknya, orang tua atau ayah dan ibu memegang peran yang sangat penting dan sangat berpengaruh atas pendidikan anak-anaknya. ${ }^{5}$ Oleh karena pentingnya peran orang tua dalam mendidik anak-anaknya maka Sayyid Qutb memberikan syarat utama kepada orang tua sebagai penanggungjawab pendidikan yaitu moralitas dan semangat keagamaan yang harus tercermin dalam setiap perilaku dan perkataannya, sebab menurut Sayyid Qutb, orang tua harus menjadi panutan bagi anak-anaknya. Biasanya anak cepat meniru atau mencontoh apa yang diucapkan atau diperbuat orang tua di rumah tangga. ${ }^{6}$

Karena pentingnya tanggung jawab yang dimiliki oleh orang tua terhadap pendidikan anak maka menurut Yusuf Barmawi sebagai penanggungjawab, orang tua berdosa jika tidak mengemban amanah pendidikan ini, minimal ia memberikan perhatian yang cukup terhadap proses pendidikan anaknya. Ia tidak saja dapat menyekolahkan melalui pendidikan, tetapi ia juga harus berperan sebagai guru pertama yang memberikan keteladanan, mengarahkan anaknya dalam menentukan masa depan dan lain-lain. ${ }^{7}$

Secara terperinci berikut ini merupakan tugas dan tanggungjawab orang tua dalam memberikan pendidikan bagi anaknya:

1. Menanamkan Aqidah

Aspek akidah merupakan aspek fudamental yang harus ditanamkan kepada anak sejak dini, sebab akidah dapat memberikan bimbingan secara moral dan sosial kepada anak. Menurut Abdullah 'Ulwan, diantara tugas sebagai

${ }^{3}$ Samsul Munir Amin, Bimbingan dan Konseling Islam (Jakarta, Amzah, 2010), hlm. 2.

${ }^{4}$ Hery Noer Aly, Ilmu Pendidikan islam (Jakarta: Logos, 1999), hlm. 88.

${ }^{5}$ Zakiah Daradjat, Ilmu Pendidikan Islam (Jakarta: Bumi Aksara, 2004), hlm. 35.

${ }^{6}$ Muhammad Qutb, Manhaj al-Tabiyah al-Islamiyyah (Beirut: Dar al-Syuruq, t.t), hlm. 216.

${ }^{7}$ Bakar Yusuf Barmawi, Pembinaan Kehidupan Beragama Islam pada Anak-Anak (Semarang: Dina Utama, 1993), hlm. 17. 
penanggungjawab pendidikan di rumah tangga, orang tua harus memberikan petunjuk dan mengajari anak tentang keimanan kepada Allah secara bertahap dari penginderaan akal kepada fenomena, dari parsial menuju kepada yang integral, dari yang paling sederhana kepada hal yang kompleks. ${ }^{8}$

Konsep keimanan kepada Allah tidak hanya dipahami sebagai konsep dasar tentang ketauhidann, tapi lebih jauh adalah aplikasinya dalam kehidupan anak sebagai way of life, bukan sebatas norma dan dogmatis. Sudah menjadi tanggung jawab orang tua menerangkan kepada anak-anak tentang prinsipprinsip agama serta hukum agama sehingga anak benar-benar mengerti tentang pengalaman dan pengalaman dalam beragama. ${ }^{9}$ Sedangkan implikasi penanaman akidah ini akan berdampak pada karakter dan moralitas anak sebab akhlak itu sendiri merupakan bagian dari agama.

\section{Menanamkan Nilai Sosial}

Dinamika kehidupan sosial cepat atau lambat selalu mengalami perubahan dan perkembangan di berbagai sektor kehidupan. Perubahan itu dan menimbulkan berbagai kebutuhan di semua aspek yang mengharuskan kita mengambil sikap dan mengaktualisasikan peran di dalamnya. Untuk itulah, sebagai penanggungjawab pendidikan, orang tua memiliki fungsi dan peran strategis dalam mensinergikan perubahan sosial beserta nilanya dengan perkembangan anak didik di rumah tangga sebagai penanggungjawab. ${ }^{10}$ Alquran sebagaimana menghimbau orang tua untuk berperan aktif dalam kesadaran sosial, mengajarkan anak bagaimana seharusnya berbuat baik kepada manusia dengan konsep "Amar ma'ruf dan nahi munkar". Alquran senantiasa mengingatkan manusia memiliki kepedulian terhadap lingkungan sosial, sayang dengan alam, tidak angkuh dan sombong di depan manusia. Konsep Alquran semacam ini selayaknya direalisasikan dalam pendidikan awal anak-anak di rumah tangga.

3. Membina Perkembangan Fisik, Psikis dan Intelektual

Setiap orang tua harus berupaya agar anak-anaknya tumbuh secara wajar dan baik, lepas dari berbagai ikatan, tekanan batin dan jiwa, supaya mereka merasakan ketenangan, kesenangan dan kesejukan dalam mengikuti irama perkembangan dan pertumbuhannya sehingga mereka merasakan kebahagiaan

${ }^{8}$ Abdullah Nasih Ulwan, Tarbiyah al-Aulad fiy al-Islam, Juz I (Beirut: Dar al-Salam, 1981), hlm. 162.

${ }^{9}$ Hasan Langgulung, Manusia dan Pendidikan (Jakarta: Pustaka al-Husna, 1989), hlm. 381

${ }^{10}$ Muhaimin, Konsep Pendidikan Islam (Solo: Ramadhani, 1993), hlm. 59. 
30 | TAZKIR: Jurnal Penelitian Ilmu-ilmu Sosial dan Keislaman

Vol. 05 No. 1 Juni 2019

hidup bersama orang tuanya. Sebagai penanggungjawab utama dalam pendidikan keluarga, orang tua harus memperhatikan perkembangan fisik anak, sebab ini juga akan berpengaruh terhadap perkembangan lainnya. Jika fisik diberi makan sebanyak tiga kali sehari misalnya, maka orang tua tidak boleh lupa untuk memberi makan psikis anak melalui ritual pendekatan ibadah seperti shalat dan puasa. Demikian juga, orang tua juga tidak cukup hanya memikirkan asupan gizi bagi fisik anaknya, tetapi juga orang tua harus berupaya memberikan gizi yang baik untuk perkembangan intelektualnya, hal ini hanya dapat dilakukan melalui pendidikan.

Penjelasan demi penjelasan sebagaimana yang telah disampaikan pada bagian terdahulu telah menguraikan panjang lebar mengenai tanggung jawab orang tua terhadap pendidikan. Bagian ini merupakan uraian lebih lanjut mengenai tanggung jawab pelaksanaan dan hasil dari pendidikan yang telah diberikan seorang anak terdapat dua pihak yang saling berhubungan, yaitu:

1. Pendidik: yaitu pihak yang memberikan anjuran-anjuran dan norma-norma dan berbagai macam pengetahuan dan kecakapan, pihak yang turut membentuk anak dan pihak yang turut menghumanisasikan anak;

2. Anak didik: yaitu pihak yang dididik, pihak yang diberi anjuran-anjuran, norma-norma, dan berbagai macam pengetahuan dan keterampilan, pihak yang dibentuk, dan pihak yang dihumanisasikan. ${ }^{11}$

Jika demikian hal nya, maka pertanyaan selanjutnya adalah siapa sebenarnya yang paling bertanggung jawab terhadap pendidikan, pendidik atau anak didik?, lebih lanjut Indrakusuma menyebutkan bahwa perlu melihat konteks dari objek pendidikan tersebut. Objek pendidikan ini harus dibedakan antara pendidikan bagi anak-anak dan pendidikan bagi orang dewasa. Jika objek pendidikannya adalah anak-anak yang yang serba tidak berdaya, masih menggantungkan diri pada orang lain, maka yang bertanggungjawab penuh terhadap pendidikan adalah si pendidik atau guru. Namun jika objek pendidikannya adala seorang yang telah tumbuh menjadi dewasa, maka pendidik tidak bertanggungjawab secara penuh terhadap keberhasilan peserta didik akan tetapi porsi tanggung jawab pendidikan bagi orang dewasa dibebankan lebih banyak kepada peserta didik. ${ }^{12}$ hlm. 133-134.

${ }^{12}$ Ibid., hlm. 134-136. 
Selain hal di atas pemerintah merupakan penanggungjawab pendidikan atas dasar pertimbangan sebagi berikut:

1. Pancasila yang berbunyi "keadilan sosial bagi seluruh rakyat Indonesia";

2. Bahwa pembukaan Undang-Undang Dasar Negara RI tahun 1945 mengamanatkan agar pemerintah melindungi segenap bangsa dan seluruh tumpah darah Indonesia, memajukan kesejahteraan umum, mencerdaskan kehidupan bangsa dan ikut melaksanakan ketertiban dunia berdasarkan kemerdekaan, perdamaian abadi dan keadilan sosial;

3. Bahwa UUD 1945 mengamanatkan Pemerintah mengusahakan dan menyelenggarakan satu sistem pendidikan nasional yang bertujuan meningkatkan keimanan dan ketakwaan kepada Tuhan Yang Maha Esa serta akhlak mulia dalam rangka mencerdaskan kehidupan bangsa yang diatur dengan undang-undang;

4. Undang-Undang RI Nomor 20 tahun 2003 tentang sistem Pendidikan Nasional (SISDIKNAS) yang berisi ketentuan dan ketetapan serta kebijakan pemerintah yang mengatur seluruh sistem dan komponen pendidikan yang paling terkait dan terpadu untuk mencapai tujuan pendidikan. ${ }^{13}$

Atas dasar pertimbangan di atas, sebagai penanggungjawab pendidikan, maka pemerintah berkewajiban:

1. Menyediakan Infrastruktur Pendidikan yang meliputi

a. Penyediaan sarana dan prasarana pendidikan;

b. Penyediaan tenaga pendidik;

c. Pengalokasian dana yang sesuai dengan kebutuhan.

2. Melakukan Standarisasi Nasional terhadap pendidikan yang meliputi:
a. Proses;
b. Kompetensi Lulusan;
c. Tenaga Kependidikan;
d. Evaluasi Pendidikan;
e. Kurikulum Dasar.

3. Membuat Peraturan Perundang-undangan yang disesuaikan dengan kebutuhan lokal maupun nasional, juga perbahan zaman, sebagai payung hukum berjalannya proses pendidikan.

${ }^{13}$ Peraturan Pemerintah RI. No. 20/2003 Tentang Undang-Undang Sistem Pendidikan Nasional, Bandung: Citra Umbara, 2003), hlm. 1-3. 
32 | TAZKIR: Jurnal Penelitian Ilmu-ilmu Sosial dan Keislaman

Vol. 05 No. 1 Juni 2019

Dengan demikian maka dapat disimpulkan bahwa yang memiliki tanggung jawab terhadap pendidikan adalah orang tua, pendidik dan peserta didik dan pemerintah. Berikut ini akan diuraikan bagaimana Alquran memandang tanggung jawab pendidikan baik itu tanggung jawab pendidikan sebagai orang tua, sebagai guru dan sebagai peserta didik serta sebagai pemerintah.

\section{METODE PENELITIAN}

Penelitian ini merupakan kajian pustaka tentang ayat-ayat dalam alQur'an yang membahas tentang tanggungjawab pendidikan. Dilakukan penelusuran pustaka untuk memperoleh data yang diperlukan. Al-Qur'an menjadi sumber utama dalam penelitian ini. Selanjutnya catatan lapangan dari apa yang ditemukan sebagai alat pengumpulan datanya, sehingga data dapat diolah secara kualitatif, dengan melakukan pengelompokan dan pendeskripsian atas hasil yang ditemukan.

\section{HASIL DAN PEMBAHASAN}

\section{Ayat-Ayat Tentang Tanggung Jawab Pendidikan}

Oleh karena luasnya ayat yang berhubungan dengan tanggung jawab pendidikan, sebagai mana yang terdapat didalam Alquran maka uraian berikut ini hanya akan menjelaskan surah at-Tahrim/66: 6 dan surah Luqman/31: 12-19 dengan menggunakan pendekatan analisis tafsir.

1. Memberikan pendidikan keimanan (akidah) dan akhlak

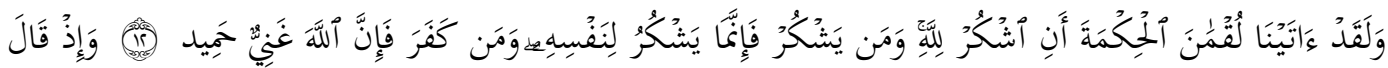

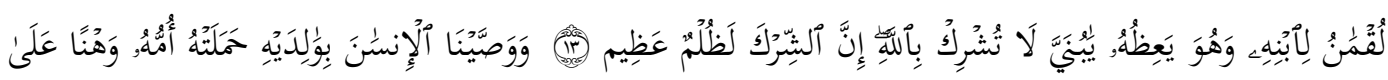

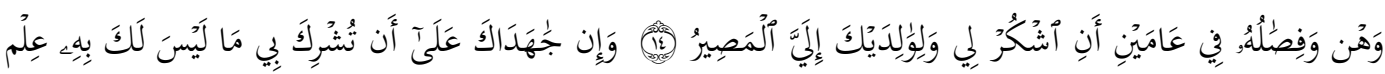

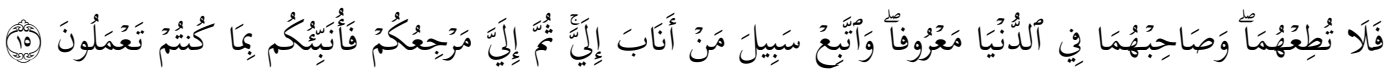

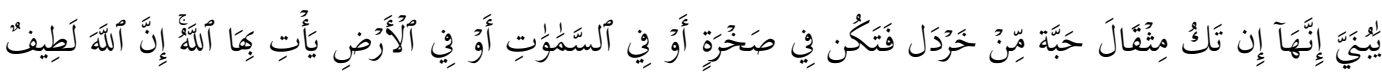

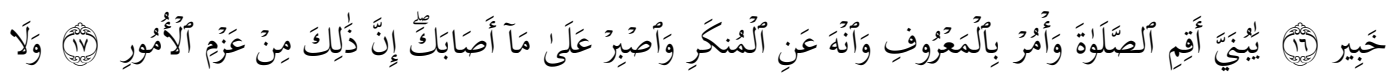




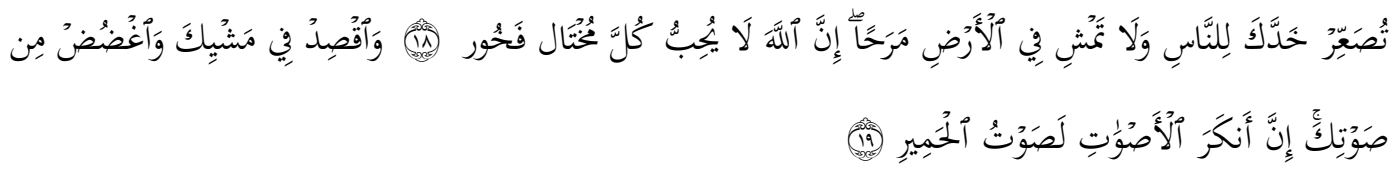

Artinya: 12) "dan Sesungguhnya telah Kami berikan hikmat kepada Luqman, Yaitu: "Bersyukurlah kepada Allah. dan Barangsiapa yang bersyukur (kepada Allah), Maka Sesungguhnya ia bersyukur untuk dirinya sendiri; dan Barangsiapa yang tidak bersyukur, Maka Sesungguhnya Allah Maha Kaya lagi Maha Terpuji". 13) dan (ingatlah) ketika Luqman berkata kepada anaknya, di waktu ia memberi pelajaran kepadanya: "Hai anakku, janganlah kamu mempersekutukan Allah, Sesungguhnya mempersekutukan (Allah) adalah benar-benar kezaliman yang besar". 14) dan Kami perintahkan kepada manusia (berbuat baik) kepada dua orang ibu-bapanya; ibunya telah mengandungnya dalam Keadaan lemah yang bertambah- tambah, dan menyapihnya dalam dua tahun, bersyukurlah kepadaku dan kepada dua orang ibu bapakmu, hanya kepada-Kulah kembalimu. 15) dan jika keduanya memaksamu untuk mempersekutukan dengan aku sesuatu yang tidak ada pengetahuanmu tentang itu, Maka janganlah kamu mengikuti keduanya, dan pergaulilah keduanya di dunia dengan baik, dan ikutilah jalan orang yang kembali kepada-Ku, kemudian hanya kepada-Kulah kembalimu, Maka Kuberitakan kepadamu apa yang telah kamu kerjakan. 16) (Luqman berkata): "Hai anakku, Sesungguhnya jika ada (sesuatu perbuatan) seberat biji sawi, dan berada dalam batu atau di langit atau di dalam bumi, niscaya Allah akan mendatangkannya (membalasinya). Sesungguhnya Allah Maha Halus lagi Maha mengetahui. 17) Hai anakku, dirikanlah shalat dan suruhlah (manusia) mengerjakan yang baik dan cegahlah (mereka) dari perbuatan yang mungkar dan bersabarlah terhadap apa yang menimpa kamu. Sesungguhnya yang demikian itu Termasuk hal-hal yang diwajibkan (oleh Allah). 18) dan janganlah kamu memalingkan mukamu dari manusia (karena sombong) dan janganlah kamu berjalan di muka bumi dengan angkuh. Sesungguhnya Allah tidak menyukai orang-orang yang sombong lagi membanggakan diri. 19) dan sederhanalah kamu dalam berjalan dan lunakkanlah suaramu. Sesungguhnya seburuk-buruk suara ialah suara keledai" (Q.S. Luqman/31: 12-19). 
34 | TAZKIR: Jurnal Penelitian Ilmu-ilmu Sosial dan Keislaman

Vol. 05 No. 1 Juni 2019

2. Menjaga diri dan keluarga dari api neraka

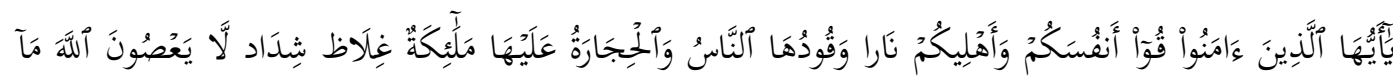

$$
\text { أَمَرَهُمْ وَيَفْعَلُونَ مَا يُوْْمَرونَ }
$$

Artinya: "Hai orang-orang yang beriman, peliharalah dirimu dan keluargamu dari api neraka yang bahan bakarnya adalah manusia dan batu; penjaganya malaikat-malaikat yang kasar, keras, dan tidak mendurhakai Allah terhadap apa yang diperintahkan-Nya kepada mereka dan selalu mengerjakan apa yang diperintahkan" (Q.S. at-Tahrim/66: 6).

\section{Penjelasan Ayat}

Di dalam Alquran surah at-Tahrim/66: 6 dijelaskan bahwa orang tua wajib bertanggungjawab menjaga anak-anak mereka dari api neraka. Menurut tafsir al-Misbah bahwa ayat ini menggambarkan pendidikan harus dimuali dari rumah. Meskipun redaksinya ditujukan kepada kepala keluarga (ayah), ini bukan berarti haya tertuju kepada laki-laki saja melainkan kepada perempuan (ibu) juga. Ini berarti bahwa kedua orang tua (ayah dan ibu) bertanggungawab terhadap anak-anak dan pasangan masing-masing. ${ }^{14}$

Dalam tafsir an-Nur dijelaskan bahwa kedudukan ayah adalah memberi pelajaran kepada anak-anaknya dan menunjuki mereka kepada kebenaran dan menjauhkan mereka dari kebinasaan. ${ }^{15}$ Sedangkan menurut tafsir al-Maraghi juga dijelaskan bahwa yang dimaksud dengan menjaga diri dan keluarga dari api neraka adalah mencakup isteri, anak, hamba sahaya, baik laki-laki maupun perempuan. Keluarga dalam ayat ini wajib mendapatkan pendidikan berupa ilmu tentang hal-hal yang wajib dikerjakan dalam agama. ${ }^{16}$

Berdasarkan surah Luqman/31: 12-19 sebagaimana yang telah dijelaskan di atas bahwa redaksi ayat ini dimulai dengan "ya bunayya", ini merupakan panggilan kesayangan dalam budaya orang Arab yang menunjukkan rasa cinta yang amat sangat dalam dari orang tua kepada anaknya. Dengan demikian maka seorang pendidik harus memahami karakteristik anak didiknya dan menghargai anak didik dengan baik. ${ }^{17}$

${ }^{14}$ M. Quraish Shihab, Tafsir Al-Misbah: Pesan, Kesan dan Keserasian Alquran, Vol. XIV (Jakarta: Lentera Hati, 2004), hlm. 327.

${ }^{15}$ Muhammad Hasby Ash-Shidieqy, Tafsir an-Nur (Semarang: Pustaka Rizki Putra, 2000), hlm. 320.

${ }^{16}$ Ahmad Musthafa al-Maraghi, Tafsir al-Maraghi (Mesir: al Babil Halabi, t.t), hlm. 162.

${ }^{17}$ Nurwadjah Ahmad, Tafsir Ayat-Ayat Pendidikan (Bandung: Marza, 2007), hlm. 167. 
Selanjutnya larangan pertama yang terdapat di dalam surah Luqman/31: 12 tersebut adalah tidak boleh berbuat syirik kepada Allah, ini berarti bahwa sejak dini para pendidik harus menciptakan lingkungan yang kondusif agar peserta didik terbebas dari kemusyrikan, serta mendorong peserta didik untuk terus mencari ilmu pengetahuan. ${ }^{18}$ Menurut keterangan Sayid Qutub dalam tafsirnya Fi Zhilalil Qur'an bahwa surah Luqman di atas mengarahkan anaknya dengan nasehat yang mengandung hikmah kebijaksanaan. Nasehat tersebut tidak mengandung tuduhan, akan tetapi mengandung persoalan ketauhidan. ${ }^{19}$

Metode pengajaran Luqman al-Hakim dengan anaknya sebagaimana yang terdapat dalam surah Luqman ini dinisbatkan oleh ulama ilmu jiwa modern dengan metode pendidikan dengan nasehat. Metode ini harus diiringi dengan metode keteladanan. Keteladanan yang baik merupakan satusatunya sarana untuk mewujudkan tujuan nasehat yang dimaksud. Seandainya Luqman tidak memiliki teladan yang baik, maka nasehat tidak akan berbekas kepada anaknya dalam jangka waktu yang lama. ${ }^{20}$ Hendaknya orang tua menjadi teladan dalam kehidupan anaknya. Sederhananya. tidak boleh menyuruh anak sholat jika orang tua sendiri tidak melaksanakan sholat. Asfiati ${ }^{21}$ mengungkapkan bahwa pendidikan bangsa muncul dari nilai-nilai yang terkandung dalam al-Qur'an dan Sunnah. Pendidikan anak-anak bangsa harus mendasar pada al-Qur'an dan sunnah, sehingga dapat menghasikkan generasi bangsa yang lebih baik dan bermoral. Hal ini didukung dengan pendapat Zulhammi ${ }^{22}$ bahwa pendidikan itu bukan hanya tergantung dari metode dan ilmunysa saja, melainkan tergantung dari lingkungan. Keluarga adalah lingkungan dimana anak dididik untuk memperoleh ilmu pengetahuan, baik ilmu umum maupun ilmu agama. Oleh karenanya, keluarga juga harus menjadi contoh teladan bagi anak-anaknya untuk memperoleh pendidikan.

Tanggung jawab pendidikan dari orang tua kepada anaknya maupun dari seorang guru kepada muridnya hendaknya tidak hanya sebatas kepada

\footnotetext{
${ }^{18}$ Nurwadjah Ahmad, Tafsir Ayat-Ayat, hlm. 167

${ }^{19}$ Sayyid Qutub, Tafsir Fi Zhilalil Qur'an: Di bawah Naungan Al-Qur'an, Jilid IX, Terj. As'ad Yasin, (Jakarta: Gema Insani Press, 2004), hlm. 164.

${ }^{20}$ Hasan Mansur, Metode Islam dalam Mendidik Remaja (Jakarta: Mustaqim, 2002), hlm. 158.

${ }^{21}$ Asfiati Hasibuan, "I'jaz Al-Qur'an in the Views of Al-Zamakhsyari and Sayyib Quthb Futurologi Pendidikan ISlam," FITRAH:Jurnal Kajian Ilmu-Ilmu Keislaman 8, no. 1 (2014): 107, https://doi.org/10.24952/fitrah.v8i1.342.

${ }^{22}$ Zulhammi Zulhammi, “Lingkungan Pendidikan Menurut Al-Qur'an,” FORUM PAEDAGOGIK Jurnal Pendidikan Agama Islam 6, no. 01 (2015), http://jurnal.iainpadangsidimpuan.ac.id/index.php/JP/article/view/172.
} 
36 | TAZKIR: Jurnal Penelitian Ilmu-ilmu Sosial dan Keislaman

Vol. 05 No. 1 Juni 2019

tanggung jawab keimanan saja, akan tetapi anak juga perlu di bekali dengan keterampilan (skill) yang berguna bagi kehidupannya kelak, anak-anak harus diciptakan untuk bisa hidup mandiri, mengikuti tantangan zaman agar mereka tidak menjadi beban orang lain.

\section{KESIMPULAN}

Berdasarkan penjelasan terdahulu maka makalah ini disimpulkan sebagai berikut:

1. Tanggung jawab pendidikan sebagaimana judul makalah ini sesungguhnya diberikan kepada empat kelompok yaitu: orang tua, pendidik, peserta didik dan pemerintah yang memfasilitasi keberlangsungan pendidikan.

2. Tanggung jawab orang tua di dalam keluarga terhadap anaknya sangat besar. Sebab secara alamiah anak pada masa awal kehidupannya berada di tengah-tengah ibu dan bapaknya dari sinilah kemudian anak memperoleh pendidikan, baik itu sikap hidup, pandangan hidiup sampai kepada keterampilan hidup.

3. Pada lembaga pendidikan, orang yang diberikan wewenang tanggung jawab adalah guru atau pendidik, karena anak didik masih memerlukan ketergantungan kepada orang lain, namun pada lembaga pendidikan tinggi yang menjadi penanggungjawab pendidikan adalah peserta didik (mahasiswa) itu sendiri.

4. Adapun pemerintah merupakan sekumpulan orang-orang yang diberikan wewenang tanggungjawab untuk memfasilitasi dan mengawasi pendidikan untuk mencerdaskan kehidupan bangsa. 


\section{DAFTAR PUSTAKA}

Ahmad, Nurwadjah. Tafsir Ayat-Ayat Pendidikan. Bandung: Marza, 2007.

Aly, Hery Noer. Ilmu Pendidikan Islam. Jakarta: Logos. 1999.

Amin, Samsul Munir. Bimbingan dan Konseling Islam. Jakarta, Amzah. 2010.

Ash-Shidieqy, Muhammad Hasby. Tafsir an-Nur. Semarang: Pustaka Rizki Putra. 2000.

Al-Maraghi, Ahmad Musthafa. Tafsir al-Maraghi. Mesir: al Babil Halabi. tt.

Barmawi, Bakar Yusuf. Pembinaan Kehidupan Beragama Islam pada Anak-Anak. Semarang: Dina Utama. 1993.

Daradjat, Zakiah. Ilmu Pendidikan Islam. Jakarta: Bumi Aksara. 2004.

Departemen Pendidikan Nasional. Kamus Besar Bahasa Indonesia: Edisi Ketiga. Jakarta: Balai Pustaka. 2007.

Hasibuan, Asfiati. "I'jaz Al-Qur'an in the Views of Al-Zamakhsyari and Sayyib Quthb Futurologi Pendidikan ISlam." FITRAH:Jurnal Kajian Ilmu-Ilmu Keislaman 8, no. 1 (2014): 107. https://doi.org/10.24952/fitrah.v8i1.342.

Indrakusuma, Amir Daien. Pengantar Ilmu Pendidikan. Surabaya: Usaha Nasional. 1973.

Langgulung, Hasan. Manusia dan Pendidikan. Jakarta: Pustaka al-Husna. 1989.

Mansur, Hasan. Metode Islam dalam Mendidik Remaja. Jakarta: Mustaqim. 2002.

Muhaimin. Konsep Pendidikan Islam. Solo: Ramadhani. 1993.

Peraturan Pemerintah RI. No. 20 Tentang Undang-Undang Sistem Pendidikan Nasional. Bandung: Citra Umbara. 2003.

Prasetya, Joko Tri. Ilmu Budaya Dasar. Jakarta: Rineka Cipta. 1998.

Shihab, M. Quraish. Tafsir Al-Misbah: Pesan, Kesan dan Keserasian Alquran, Vol. XIV. Jakarta: Lentera Hati. 2004.

Qutb, Muhammad. Manhaj al-Tabiyah al-Islamiyyah. Beirut: Dar al-Syuruq. Tt. 
38 | TAZKIR: Jurnal Penelitian Ilmu-ilmu Sosial dan Keislaman

Vol. 05 No. 1 Juni 2019

Tafsir Fi Zhilalil Qur'an: Di bawah Naungan Al-Qur'an, Jilid IX, Terj. As'ad Yasin. Jakarta: Gema Insani Press. 2004.

Ulwan, Abdullah Nasih. Tarbiyah al-Aulad fiy al-Islam, Juz I. Beirut: Dar al-Salam. 1981.

Zulhammi, Zulhammi. “Lingkungan Pendidikan Menurut Al-Qur'an." FORUM PAEDAGOGIK Jurnal Pendidikan Agama Islam 6, no. 01 (2015). http://jurnal.iainpadangsidimpuan.ac.id/index.php/JP/article/view/172. 